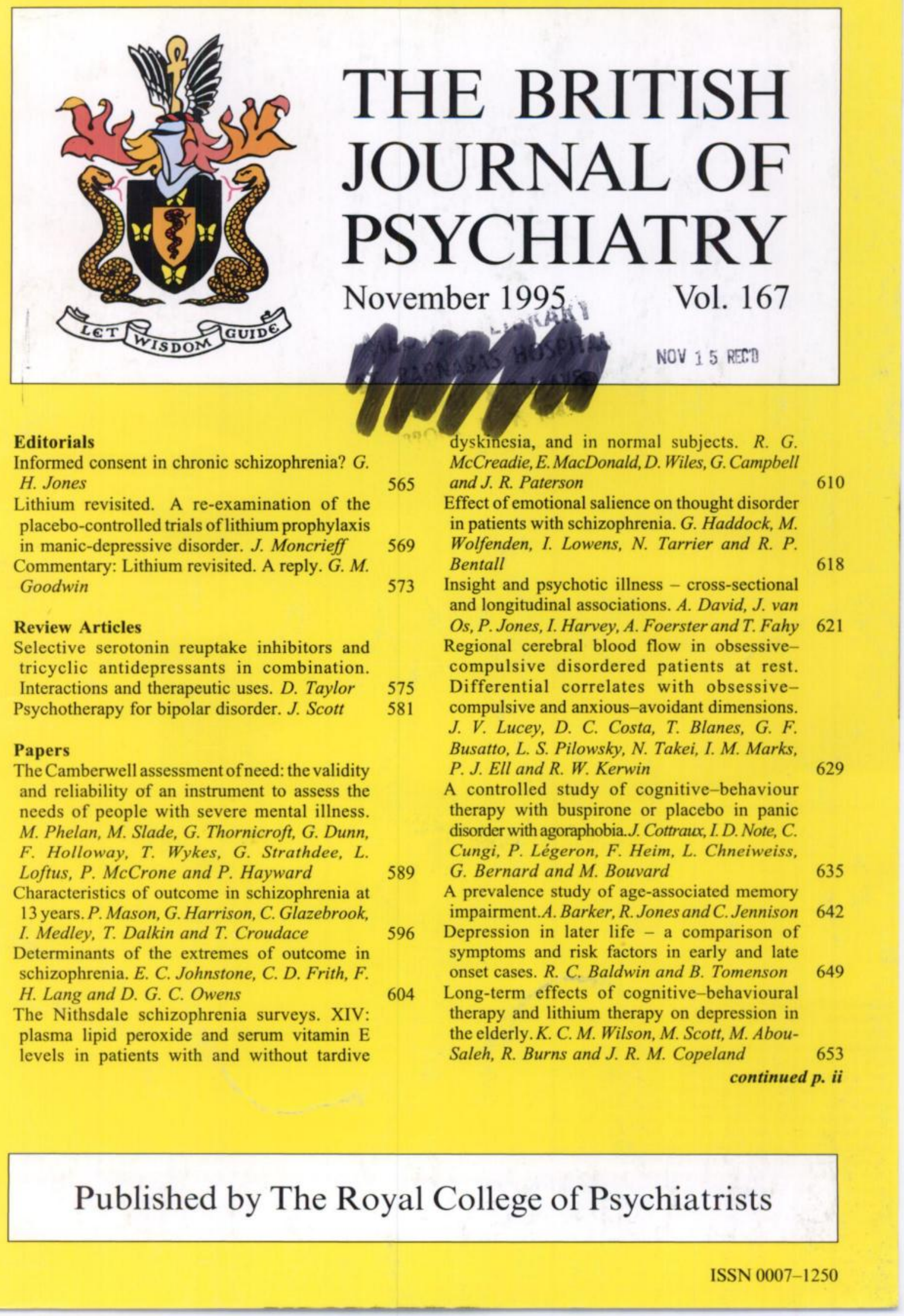




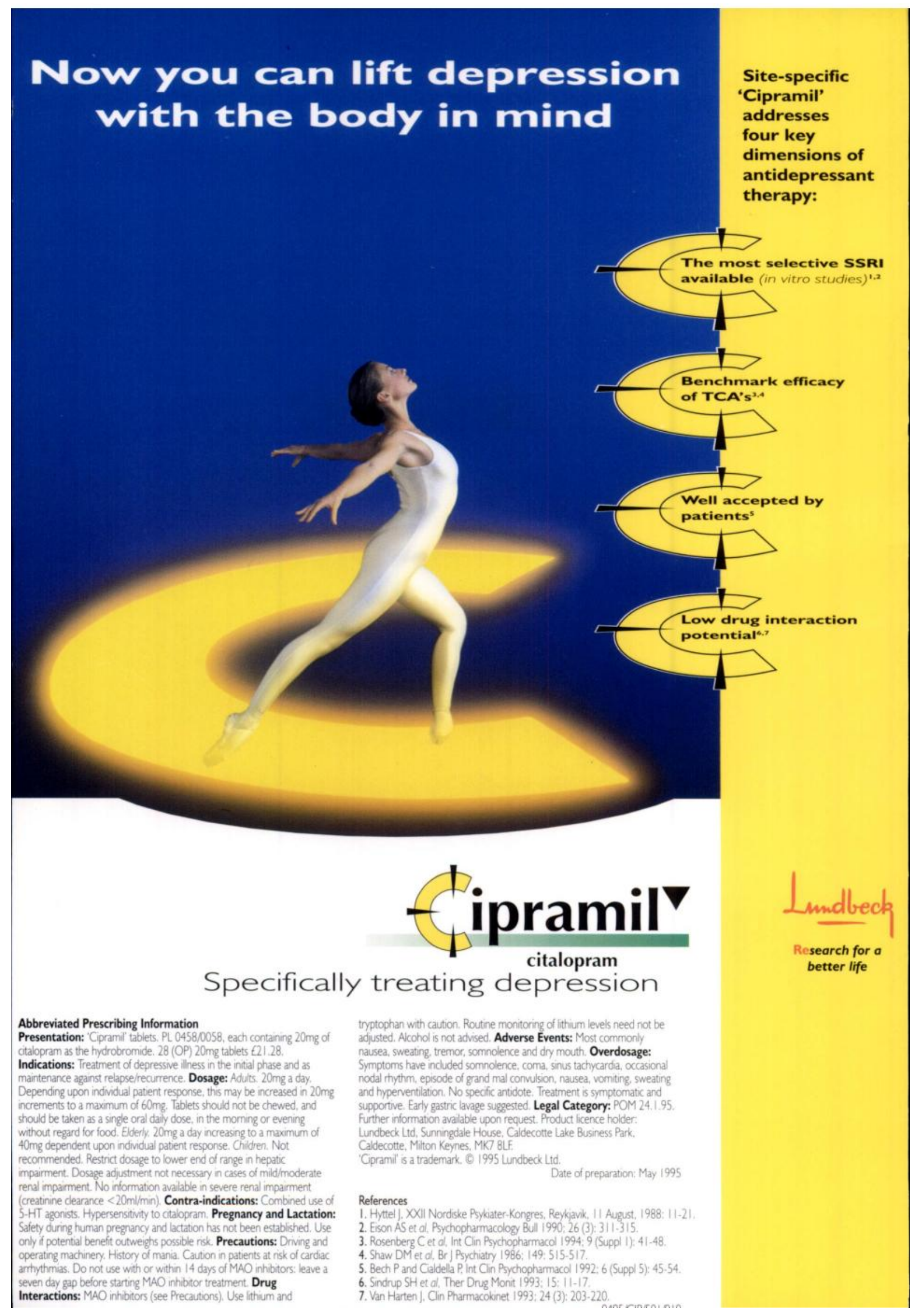




\section{The British Journal of Psychiatry}

November 1995

Volume 167

№. 5

\section{Editor Greg Wilkinson}

\begin{tabular}{l} 
Senior Associate Editor \\
Alan Kerr Newcastle upon Tyne \\
Associate Editors \\
Sidney Crown London \\
Julian Leff London \\
Sir Martin Roth Cambridge \\
Sir Michael Rutter London \\
Peter Tyrer London \\
\multicolumn{1}{c}{ Editorial Advisers } \\
Herschel Prins Leicester \\
Sir John Wood Sheffeld \\
Kathleen Jones York \\
\multicolumn{1}{c}{ Assistant Editors } \\
Mohammed Abou-Saleh Al-Ain \\
Louis Appleby Manchester \\
German Berrios Cambridge \\
Alistair Burns Manchester \\
Patricia Casey Dublin \\
John Cookson London \\
David Cottrell Leeds \\
Nigel Eastman London \\
Tom Fahy London \\
Anne Farmer Cardiff \\
Michael Farrell London \\
Nicol Ferrier Newcastle upon Tyne \\
William Fraser Cardiff \\
Richard Harrington Manchester
\end{tabular}

Sheila Hollins London
Jeremy Holmes Barnstaple
Alexander Kellam Cardiff
Peter Kennedy York
Alan Lee Nottingham
Shôn Lewis Manchester
Robin McCreadie Dumfries
Ian McKeith Newcastle upon Tyne
Roy McClelland Belfast
Stuart Montgomery London
David Owens Leeds
Ian Pullen Edinburgh
Rosalind Ramsay London
Henry Rollin London
Jan Scott Newcastle upon Tyne
Andrew Sims Leeds
Jeanette Smith Bristol
George Stein London
David Tait Perth
Corresponding Editors

Sidney Bloch Australia

Patrice Boyer France

J.M. Caldas de Almeida Portugal

Andrew Cheng Taiwan

Andrei Cristian Romania

E. L. Edelstein Israel

Václav Filip Czech Republic

Heinz Katschnig Austria

Kenneth Kendler USA
Toshi Kitamura
Arthur Kleinman USA
F. Lieh Mak Hong Kong
Jair Mari Brazil
Harold Merskey Canada
Paul Mullen Australia
Ahmed Okasha Egypt
Volodymer Poltavetz Ukraine
Michele Tansella Italy
Toma Tomov Bulgaria
John Tsiantis Greece
J.L. Vázquez-Barquero Spain
Richard Warner USA

Statistical Adviser

Pak Sham London

Staff

Publications Manager

Dave Jago

Scientific Editor

Lesley Bennun

Deputy Scientific Editor

Aliki Buhayer

Assistant Scientific Editor

Dinah Alam

Editorial Assistants

Judy Ashworth

Julia Burnside

Marketing Assistant

Dominic Bentham

\section{Past Editors}

Eliot Slater 1961-72 Edward H. Hare 1973-77 John L. Crammer 1978-83 Hugh L. Freeman 1984-93

Founded by J. C. Bucknill in 1853 as the Asylum Journal and known as the Journal of Mental Science from 1858 to 1963 
Contents continued from front cover

Further evidence that reading ability is not preserved in Alzheimer's disease. $R$. $E$. O'Carroll, No Prentice, C. Murray, M. van Beck, K. P Ebmeier and G. M. Goodwin

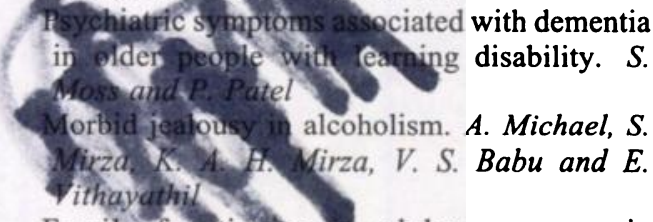

Family furetioniling in adolescent anorexia nervosa. C. North, S. Gowers and V. Byram The signifieance of a history of childhood sexual abuse in bulimia nervosa. P. F. Sullivan, $C . M$. Bulik, F. A. Carter and P. R. Joyce

The British Journal of Psychiatry is published monthly by the Royal College of Psychiatrists (a registered charity, registration number 228636). The $B J P$ publishes original work in all fields of psychiatry. All communications, including manuscripts for publication, should be sent to the Editor, British Journal of Psychiatry, 17 Belgrave Square, London SW1X 8PG.

Full instructions to authors are given at the beginning of the January and July issues.

\section{Subscriptions}

Non-members of the College should contact the Publications Subscription Department, Royal Society of Medicine Press Limited, PO Box 9002, London W1A OZA (tel. 0171290 2928;fax 0171290 2929). Annual subscription rates for 1995 (12 issues post free) are as follows:

Europe (\& UK): institutions $£ 148$, individuals $£ 130$ US: institutions $\$ 295$, individuals $\$ 210$

Elsewhere: institutions $£ 175$, individuals $£ 138$

Full airmail is $£ 36 /$ US\$64 extra.

Single copies of the Journal are $£ 14, \$ 25$ (post free).

Payment should be made out to the British Journal of Psychiatry.

Queries from non-members about missing or faulty copies should be addressed within six months to the same address; similar queries from College members should be addressed to the Registration Subscription Department, The Royal College of Psychiatrists, 17 Belgrave Square, London SW1X 8PG.

(C) 1995 The Royal College of Psychiatrists. Unless so stated, material in the British Journal of Psychiatry does not necessarily reflect the views of the Editor or the Royal College of Psychiatrists. The publishers are not responsible for any error of omission or fact.
The use of statistics in the British Journal of Psychiatry. S. M. McGuigan

Improving the quality of statistics in psychiatric research. D. Hand and $P$. Sham

\section{Columns}

Correspondence 692

A hundred years ago 700

Book reviews 701

American Journal of Psychiatry (contents) $\quad 707$

\begin{tabular}{|l|} 
Next month in the BJP \\
Brain atrophy in normal ageing and Alzheimer's \\
disease. Volumetric discrimination and clinical \\
correlations. H. Förstl, R. Zerfaß, C. Geiger- \\
Kabisch, H. Sattel, C. Besthorn and F. Hentschel
\end{tabular}

\section{Back issues}

Back issues published before 1995 may be purchased from William Dawson \& Sons Ltd, Cannon House, Folkestone, Kent (tel. 01303850 101).

\section{Advertising}

Correspondence and copy should be addressed to Peter T. Mell, Advertising Manager, PTM Publishers Ltd, 282 High Street, Sutton, Surrey SM1 IPQ (tel. 0181 642 0162; fax 01816432275 ).

\section{US Mailing Information}

The British Journal of Psychiatry is published monthly by the Royal College of Psychiatrists. Subscription price is $\$ 295$. Second class postage paid at Rahway, NJ. Postmaster send address corrections to the British Journal of Psychiatry, c/o Mercury Airfreight International Ltd Inc., 2323 Randolph Avenue, Avenel, New Jersey 07001.

๑тм The paper used in this publication meets the minimum requirements of American National Standard for Information Sciences - Permanence of Paper for Printed Library Materials. ANSI Z39.48-1984.

Typeset by Dobbie Typesetting Ltd, Tavistock, and Henry Ling Ltd.

Printed by Henry Ling Ltd, The Dorset Press, 23 High East Street, Dorchester, Dorset DT1 1HD. 


\section{SIMPLE AND EFFECTIVE E.C.T. WITH THE ECTONUS AND ECTONUSTIM}

\section{Constant Current Series 5A ECT apparatus}

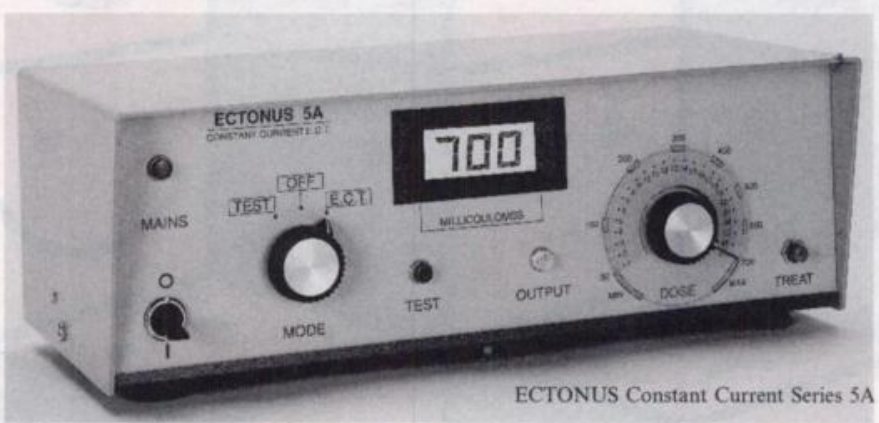

Also now available:

Series 5B E.C.T. Apparatus

Send for full details

\section{ECTRDN LTID}

KNAP CLOSE LETCHWORTH HERTS ENGLAND SG61AQ

Telephone $01462682124 \quad$ Fax 01462481463

\section{Dr. Paul Janssen schizophrenia Research Award \\ CINP collegium Intemationale Neuro- Psychopharmacologicum}

Year of 2nd Award: 1996 (Period June 1994-June 1996)

What? Every two years a scientific award, amounting to US\$ 25,000 , provided by the CINP (Collegium Internationale Neuro-Psychopharmacologicum) through an educational grant from Janssen Research Council.

Who? Any young investigator lless than 45 years old on January 1 st of the year of the award) who has performed outstanding research in the area of Clinical Neuroscience of Schizophrenia at a university institute or any other acknowledged scientific institution that is independent of the pharmaceutical industry. The submitted work should, at least in part, be the result of investigations conducted by the candidate during the five years preceding the year of award.

When? The recipient of the Dr. Paul Janssen Schizophrenia Research Award will be chosen by an international scientific jury, at least two months prior to the opening ceremony of the CINP Congress. The second Award will be presented at the opening ceremony of the XXth CINP Congress in Melbourne in 1996.

Whom to contact? For obtaining more detailed regulations of the Award: Dr. Luc Tritsmans, International Clinical R\&D Department, Janssen Research Foundation, Turnhoutseweg 30, B.2340 Beerse, Belgium

For CINP application forms and submissions:

Prof. Goran Sedvall, Department of Psychiatry, Karolinska Hospital. S-171 76. Stockholm, Sweden

\section{ROYAL SOCIETY OF MEDICINE SECTION OF PSYCHIATRY}

\section{MENTAL HEALTH FOUNDATION ESSAY PRIZE}

This prize is to be awarded for an original essay with particular relevance to Psychiatry.

Entry is invited from candidates currently practising medicine in the UK or Republic of Eire, and in training at any grade from

Senior House Officer to Senior Registrar or equivalent.

The winner and runner up may be invited to present their papers at a meeting of the Section of Psychiatry during the session.

Closing date for entries is 31 March 1996

For a complete copy of the regulations, please contact:

$$
\begin{aligned}
& \text { Mrs Alyson Ling, Section Administrator } \\
& \text { Tel: } 01712902985 \\
& \text { Fax: } 01712902989
\end{aligned}
$$

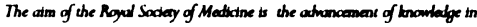

$$
\begin{aligned}
& \text { all fiold of matione and alliad subjeas }
\end{aligned}
$$




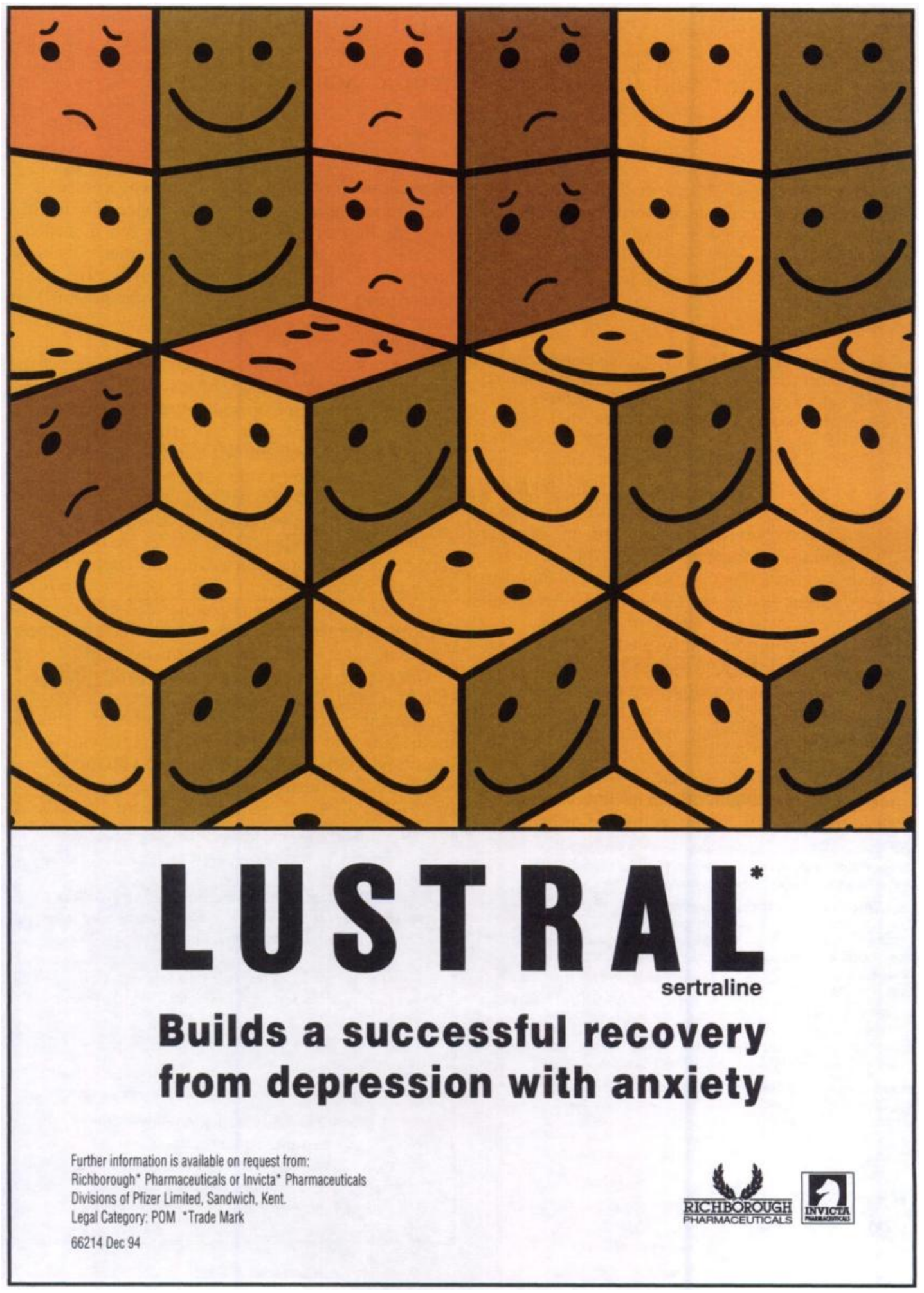

